\title{
SIMBOL DAN ORNAMEN-SIMBOLIS PADA ARSITEKTUR GEREJA KATOLIK REGINA CAELI DI PERUMAHAN PANTAI INDAH KAPUK-JAKARTA
}

\author{
Reginaldo Christophori Lake ${ }^{1}$, Yohanes Djarot Purbadi², Robertus M. Rayawulan, \\ Richardus Daton, Efraim Desprinto Lalu \\ Universitas Katolik Widya Mandira \\ Universitas Atma Jaya Yogyakarta \\ 1egilake@yahoo.com \\ 2djarot.purbadi@uajy.ac.id
}

\begin{abstract}
Abstrak: Bangunan Gereja Katolik selalu menampilkan simbol dan ornamen-simbolis sebagai ungkapan iman dan suasana relijius (sakral). Simbol-simbol berupa obyek dua dimensi dan tiga dimensi ditata dan memperindah gereja sekaligus bermakna relijius. Simbol dan ornamen-simbolis diletakkan di dalam gereja (interior) dan di luar gereja (eksterior), berfungsi mendukung suasana gereja secara visual dan membantu penghayatan iman secara estetis, psikologis dan relijius. Gereja Katolik Regina Caeli di Pantai Indah Kapuk Jakarta adalah gereja katolik yang berciri arsitektur modern dan dilengkapi simbol dan ornamen-simbolis pada interior dan eksterior gereja. Tulisan ini mendeskripsikan keberadaan simbol dan ornamen-simbolis pada gereja dikaitkan dengan ketaatan pada prinsip-prinsip arsitektur modern yang mendasari rancangan gereja. Permasalahan penelitian adalah bagaimana keberadaan simbol dan ornamen simbolis dalam Gereja Katolik Regina Caeli yang berarsitektur modern-minimalis? Kajian dilakukan dengan menganalisis data sekunder (foto dan teks) dan studi pustaka, selanjutnya dikomparasikan dengan pedoman dasar arsitektur gereja katolik dan prinsip-prinsip arsitektur modern. Hasilnya, arsitektur Gereja Katolik Regina Caeli merupakan arsitektur modern dengan ekspresi modern-minimalis. Keberadaan simbol salib menandai keberadaan gereja katolik secara visual, ornamen-simbolis interior menguatkan keunikan sebagai ruang sakral (relijius). Gereja Katolik Regina Caeli berlanggam arsitektur modern dan memberi tempat bagi kehadiran simbol dan ornamen-simbolis; terjadi percampuran antara arsitektur modern dengan simbolisme gereja sebagai bangunan ibadah.

Kata kunci: simbol, ornamen-simbolis, arsitektur gereja katolik, fungsi, makna
\end{abstract}

\begin{abstract}
The Catholic Church building always displays symbols and ornaments as an expression of religious (sacred) faith and atmosphere. Symbols in the form of two-dimensional and three-dimensional objects arranged and beautified the church as well as religious significance. Symbols and ornaments are placed inside the church (interior) and outside the church (exterior), function to support the atmosphere of the church visually and help appreciate aesthetic, psychological and religious faith. Regina Caeli Catholic Church in Pantai Indah Kapuk Jakarta is a Catholic church that is characterized by modern architecture and features symbols and ornaments on the interior and exterior of the church. This paper describes the existence of symbols and ornaments symbols in the church associated with obedience to the principles of modern architecture that underlies the design of the church. The research problem is how the existence of symbolic symbols and ornaments in the Regina Caeli Catholic Church, which are modern-minimalist architecture? The study was carried out by analyzing secondary data (photos and texts) and literature studies, then compared with the basic guidelines of Catholic church architecture and the principles of modern architecture. As a result, Regina Caeli's Catholic Church architecture is a modern architecture with a modern-minimalist expression. The existence of a symbol of the cross marks the existence of a Catholic church visually, the interior ornaments strengthen the uniqueness as a sacred (religious) space. The Regina Caeli Catholic Church has a modern architecture and provides a place for symbolic symbols and ornaments; there is a mixture of modern architecture with church symbolism as a relogious building.

Keyword: symbols, ornaments, church architecture, functions, meanings, Regina Caeli church
\end{abstract}

\section{PENDAHULUAN}

Desain tempat ibadah selalu didasari ajaran dan nilai agama, perilaku ritual umat dan suasana sakral (relijius) tertentu yang ingin diwujudkan. Prinsip dasar ini berlaku juga bagi desain 
gereja katolik di Indonesia. Desain Gereja Katolik umumnya berusaha memancarkan ekspresi eksistensial sakral yang didasari oleh nilai katolik [1]. Pada sisi lain, dalam alam kehidupan dan budaya modern, sakralitas pada ekspresi arsitektur gereja katolik cenderung melemah karena pergeseran relasi fungsi, bentuk dan makna pada gereja [2]. Simbolisme pada tempat ibadah selalu menjadi unsur penting, apalagi jika ada kemenyatuan simbolisme dalam agama dengan simbolisme dalam budaya lokal menunjukkan adanya integrasi harmonis agama dan budaya lokal. Simbolisme campuran terjadi pada beberapa fasilitas ibadah: katolik dan budaya Toraja [3]; Islam dan budaya Jawa [4]; atau katolik dengan budaya Bali [5]. Artinya, simbolisme menjadi unsur penting dalam agama dan budaya yang dihayati oleh masyarakat setempat. Simbolisme juga penting dalam arsitektur gereja katolik, sebab simbol menjadi wahana untuk menghayati liturgi sekaligus menciptakan pengalaman relijius, estetis dan psikologis [6]. Simbolisasi secara meruang diletakkan pada eksterior dan interior bangunan [7], bahkan tata ruang-dalam dan elemen-elemen simbolisasi ditentukan oleh liturgi, seperti terjadi pada desain interior Gereja Kelahiran Santa Perawan Maria di Surabaya [8]. Oleh karenanya, perubahan-perubahan arsitektur gereja katolik hampir selalu terjadi pada elemenelemen eksterior dan interior untuk menampilkan simbolisme yang tepat sesuai kebutuhan iman. Perubahan interior gereja katolik mengacu pada iman dasar yaitu Tri Tunggal Maha Kudus yang menjadi pegangan utama, seperti terjadi pada renovasi gereja katolik Santo Paulus di Surabaya [9]. Perubahan selalu terjadi pada desain gereja, namun keberadaan unsur-unsur baru biasanya selalu diusahakan harmonis dengan unsur-unsur lama (misalnya, unsur arsitektur kolonial) [10]. Contoh lain, pencahayaan interior yang berasal dari gaya arsitektur gotik pada gereja lama, misalnya, dipertahankan karena menjadi faktor penentu ekspresi suasana spiritual [11]. Bagaimanapun juga, arsitektur gereja katolik harus taat dan memperhatikan relasi kuat tiga elemen: fungsi, makna dan bentuk [12]. Awalnya, arsitektur gereja katolik didominasi langgam arsitektur Eropa, Kolonial Belanda, bahkan langgam Gotik. Data menunjukkan langgam Gotik muncul pada arsitektur gereja katolik tertua di Makasar, yaitu gereja katedral [13]. Arsitektur gereja bergaya arsitektur Eropa juga ada di Surabaya yaitu Gereja Hati Kudus Yesus [14] dan Gereja Katolik Santo Paulus [15]. Bentuk gereja dengan gaya arsitektur Neo-Gotik terdapat pada Gereja Purbayan di Solo [16]. Arsitektur gereja katolik bergaya Eropa dan Kolonial tersebar pada berbagai kota yang pernah menjadi basis VOC melakukan aktivitasnya di Indonesia. Dalam perkembangan di Indonesia, arsitektur gereja katolik mengalami perubahan, antara lain terjadi inkulturasi atau akulturasi, yaitu penggunaan elemen-elemen budaya lokal dalam arsitektur gereja untuk melengkapi keberadaan elemen-elemen Eropa. Pada tahap lanjutan, arsitektur modern masuk ke Indonesia dan diserap oleh para arsitek, sehingga muncul desain- desain gereja katolik yang menggunakan tampilan arsitektur modern. Fenomena gereja katolik dengan arsitektur modern menambah kekayaan arsitektur di Indonesia. Sejak tahun 2010 bahkan banyak muncul rancangan gereja katolik bergaya arsitektur modern-minimalis, khususnya di perumahan-perumahan sebagai fasilitas publik. Oleh karenanya, karakteristik rancangan gereja katolik bergaya arsitektur modern-minimalis merupakan salah satu obyek penelitian yang masih terbuka dan belum banyak diteliti.

\subsection{Elemen Penting dalam Arsitektur Gereja Katolik}

Gereja mengandung dua pengertian, yaitu umat Allah dan bangunan atau gedung tempat umat melakukan ibadat. Gereja sebagai umat Alla adalah orang-orang yang terhimpun menjadi satu tubuh dalam kesatuan dengan tubuh mistik Kristus. Artinya orang-orang pengikut Kristus yang selalu dekat dan mengikuti semua ajaran dan perintahnya. Gereja 
sebagai bangunan atau gedung merupakan wadah bagi umat untuk melakukan kegiatan keagamaan dan berbagai kegiatan lain yang terkait dengan keimanan dan ritual. Rancangan gereja sebagai wadah fisik sangat ditentukan oleh keberadaan konsep ruang sakral (sacred space) [17]. Menurut Srisadono (2012) arsitektur gereja pada intinya adalah ruang (space) yang sakral: sacred space, diilhami oleh makna kehadiran Tuhan yang mendatangi umatnya. Dalam tradisi gereja Katolik, sacred space diartikan sebagai kenisah atau bait suci Allah. Gereja sebagai wadah "sacred space" ketika "Tuhan" harus diberi "wadah" bagi kehadiranNya. Kata "sacred" berasal dari kata "sacrum" (Latin), yang terkait dengan Tuhan dan kekuatan kuasa-Nya; dalam kata ini juga terkandung makna "spatial" yang menunjuk pada area atau ruang tertentu. Arti lain yang berkaitan adalah "keberadaan" ("being") yang dihayati oleh manusia religius sebagai pusat eksistensi keberadaan dan tujuan hidupnya. Kata lain yang sepadan adalah "holy" "divine"; "transcendent"; "ultimate being"; "ultimate reality"; "mystery"; "perfection"; "purity". Sedangkan kata "space" berasal dari kata "spatium" (Latin) yang dalam Bahasa sehari-hari berarti "kekosongan" di luar tubuh; "jarak" antar tubuh ("Space" dalam "Catholic Encyclopedia"). Dengan demikian makna frasa "sacred space" adalah "kekosongan" yang diisi oleh "kehadiran Tuhan dengan kekuatan-Nya" yang mampu dirasakan oleh manusia. Bentuk arsitektur untuk tempat ibadah tertentu menekankan unsur vertikal sebagai simbol "pencapaian" terhadap Tuhan. Contohnya adalah menara Gereja atau menara Masjid; juga bentuk stupa yang meruncing ke atas pada bangunan Vihara atau juga ujung-ujung lancip pada Vihara; bentuk-bentuk arsitektur tersebut seolah hendak "meraih Tuhan di langit" ini membantu pengguna tempat ibadah tersebut untuk mengarahkan pandangan pada Tuhan di atas mereka. Pada bangunan Vihara dan Pura yang tanpa atap dan langsung "beratap langit" unsur vertikal tersebut dengan mudah menuntun secara visual pada langit yang sesungguhnya [17]. Simbol Salib merupakan salah satu elemen penting dalam gereja akatolik sebagai komunitas maupun sebagai gedung. Salib selalu ada dalam kehidupan orang katolik, bahkan terlalau sering digunakan dalam doa-doa harian. Salib dalam gereja selalu ada dua, yaitu terletak di luar gereka dan di dalam gereja. Salib di luar gereja digunakan untuk memberi tanda, sebagai tanda bahwa gedung adalah bangunan gereja. Salib di dalam ruangan menjadi sarana untuk mendukung doa, berdoa di depan salib menjadi lebih bermakna dibandingkan dengan berdoa di depan benda yang tidak menyimbolkan apa-apa.

Ornamen Jalan Salib merupakan elemen penting lain di dalam bangunan gereja katolik karena panel-panel jalam salib sebanyak 14 panel menjadi sarana berdoa mengenang sengsara Yesus ketika disalib. Dalam agama katolik, mengenang berarti mengalami kembali peristiwa masa lalu, dan itu artinya Yesus hadir pada saat ritual terjadi. Mengingat pentingnya filosofi ini, maka setiap Misa Kudus umat mengalami langsung kehadiran Yesus dalam wujud roti dan anggur. Bukan simbol lagi melainkan sungguh terjadi. Demikianlah ajaran iman katolik tentang Misa Kudus. Ornamen-simbolis yang lain adalah panel plafond alfa dan omega. Simbol alfa dan omega merupakan simbol penting dalam gereja katolik. Yesus dilambangkan dengan dua huruf, alfa dan omega, artinya awal dan akhir yang menjadi satu. Panel dengan tulisan alfa dan omega pada ruang altar mengingatkan dan memperkuat keyaiknan umat bahwa Yesus-lah awal dan akhir kehidupan. Keberadaan ornamen simbolis ini memperkuat simbol-simbol secara keseluruhan dan sutuhnya.

\subsection{Penelitian Arsitektur Gereja Katolik di Indonesia}

Penelitian dengan obyek arsitektur gereja katolik telah banyak dilakukan. Penelitian tentang keberadaan gaya arsitektur Eropa pernah dilakukan pada ruang-dalam (interior) Gereja Hati Kudus Yesus di Surabaya [14] dan Gereja Katolik Santo Paulus [15]. Bentuk gereja dengan gaya arsitektur Neo-Gotik terdapat pada Gereja Purbayan di Solo [16]. Dalam perkembangan 
selanjutnya, arsitektur gereja Katolik mengalami perubahan, ditemukan terjadi inkulturasi, penggunaan elemen-elemen budaya lokal dalam arsitektur gereja melengkapi keberadaan elemen-elemen Eropa. Penelitian inkulturasi dalam desain gereja Katolik menemukan adanya penggunaan unsur budaya Jawa berupa zoning, elemen pembentuk ruang lantai dan plafon, warna, tata letak bangku umat dan perabot untuk pemimpin [18]. Inkulturasi dengan unsur budaya Jawa terjadi pada interior gereja, yaitu pada elemen dekorasi untuk menunjukkan keberadaan budaya Jawa [19]. Inkulturasi desain gereja dengan budaya Bali juga terjadi pada Gereja Katolik Tri Tunggal Mahakudus Tuka-Dalung di Bali [5], bahkan tata lansekap pada Gereja Katolik Santa Maria Immaculata di Tabanan Bali dilandasi filosofi Tri Hitakarana [20]. Penelitian tentang akulturasi ekspresi dan bentuk pada gereja katolik Puhsarang, menemukan prinsip-prinsip arsitektur vernakular Jawa dipadukan dengan teknologi modern oleh Maclaine Pont [21]. Penelitian tentang sinkretisme terjadi pada gereja katolik di Ganjuran, yang memberi peluang ekspresi lebih leluasa dan lengkap pada kehadiran unsurunsur budaya Jawa dalam gereja, terutama aspek fisik, perilaku hingga nilai-nilai spiritual [22] hingga musik [23]. Penelitian inkulturasi juga menemukan kejadian inkulturasi gereja katolik dengan unsur- unsur budaya Dayak, terbatas pada aspek "bahasa liturgi", yakni penggunaan bahasa Dayak Kayaan dalam liturgi gereja pada dialog, doa dan nyanyian [24]. Inkulturasi dengan budaya Cina juga muncul, namun terbatas pada elemen ornamen, terjadi pada gereja katolik Gereja Santa Maria De Fatima Jakarta Barat [25]. Inkulturasi lebih lengkap terjadi pada "desain gereja" dan "bahasa liturgi" (termasuk nyanyian dan musiknya) ditemukan di Gereja Santo Yohanes Pemandi di desa Kaenbaun, desa suku Dawan di pulau Timor [26]. Rancangan gereja katolik mendapat warna baru oleh kehadiran arsitek dan pastor YB. Mangunwijaya yang menyelesaikan pendidikan arsitektur di Jerman. Kiprahnya dalam arsitektur gereja katolik memberi warna, wawasan dan semangat baru. Gereja katolik karya YB Mangunwijaya merupakan fenomena baru yang muncul di tengah inkulturasi arsitektur barat dan lokal di Indonesia. Karya Mangunwijaya yang terkenal adalah Gereja Katolik St. Albertus Agung di Jetis, Gereja Katolik Maria Asumpta di Klaten dan Gereja Katolik Wisma Salam. Karya Mangunwijaya berakar pada pandangan yang dicetuskan dan dihayatinya dan terumuskan dalam buku Wastucitra yang ditulisnya. Menurut Mangunwijaya, cara pandang dwilogi dalam kategori Guna dan Citra lebih tepat untuk melihat arsitektur di Indonesia daripada cara Vitruvius (Istanto, 1999; Burhany, 2010) dan dapat diterapkan pada arsitektur dimanapun [29]. Selain itu, penggunaan konsep tektonika, pengolahan bahan alam secara kreatif menjadi lebih fungsional dan indah dalam setiap karya Mangunwijaya merupakan salah satu kunci kekuatan arsitektur [30], bahkan mampu memberi karakter universal sekaligus lokal (universality and locality) yang kuat dan unik [31]. Artinya, cara berpikir dan cara kerja arsitek Mangunwijaya merupakan model yang baik bagi para arsitek di Indonesia untuk menciptakan karya arsitektur yang kreatif [32] berbasis lokalitas danmenyentuh universalitas. Dilihat dari perspektif arsitektur, rancangan arsitektur gereja katolik harus memperhatikan keterkaitan tiga unsur yaitu fungsi, makna dan simbol [33]. Gereja harus berfungsi sebagai tempat ibadah khusus bagi umat, dan kegiatan lainnya yang mendukung keimanan. Gereja harus menjadi ruang yang bermakna bagi umat dalam menjalankan setiap aktivitas keagamaan, khususnya dalam kegiatan ibadah. Simbol merupakan elemen ruang atau instrumen yang memperkuat agar diperoleh suasana dan pengalaman iman yang mendalam, secara visual, rasional, psikologis dan relijius. Dari penelitian-penelitian sebelumnya terlihat adanya fokus tentang langgam, bahwa dalam desain gereja katolik di Indonesia ada pergeseran dari bergaya arsitektur Eropa (kolonial, gotik) ke arsitektur inkulturatif dan akulturatif sesuai dengan konteks tempat dan budaya setempat. Fokus berikutnya adalah percampuran arsitektur, terjadi percampuran arsitektur antara arsitektur Eropa (kolonial, gotik) dengan arsitektur setempat, misalnya Jawa, Bali dan Dayak. 
Meskipun demikian, unsur simbolisme tetap dipertahankan dan menghasilkan kreativitas dalam desain gereja, pada interior dan eksteriornya, sebab simbolisme harus selalu ada dalam gereja katolik. Tulisan ini berfokus pada keberadaan elemen-elemen simbolisme dan ornamen-simbolis dalam arsitektur gereja katolik yang dirancang dengan paradigma arsitektur modern. Tulisan ini masuk dalam tema kaitan arsitektur modern dengan simbolisme dalam agama katolik, yang belum pernah ada pada tulisan-tulisan sebelumnya.

\section{KASUS STUDI DAN METODE PENELITIAN}

\subsection{Gereja Katolik Regina Caeli di Pantai Indah Kapuk}

Gereja sebagai fasilitas publik pada perumahan-perumahan massal merupakan fenomena yang berkembang seiring dengan perkembangan kota-kota baru dan perumahan-perumahan massal di Indonesia. Salah satu fasilitas yang harus diadakan pengembang perumahan adalah fasilitas publik, termasuk fasilitas ibadah. Salah satu fasilitas ibadah yang dibangun pengembang perumahan adalah gereja sebagai fasilitas ibadah untuk umat katolik atau kristen setempat yang memenuhi syarat fungsional dan persyaratan lain. Regina Caeli adalah sebutan untuk Bunda Maria Ratu Surga. Gelar Bunda Maria sebagai Ratu surga berhubungan dengan gelar Bunda Maria Bunda Kristus, yang adalah Sang Raja di atas segala raja di bumi. Kitab Suci mengajarkan bahwa para kudus di surga akan menerima mahkota kehidupan, terlebih Bunda Maria yang adalah orang kudus yang terbesar. Kesetiaan Bunda Maria yang bertahan sampai akhir, mendatangkan mahkota kehidupan yang dijanjikan Tuhan. Pengumuman dogma mengenai Maria diangkat ke surga oleh Paus Pius XII, 1950. Gereja Katolik Regina Caeli yang diresmikan tahun 2008 dipilih sebagai salah satu contoh gereja di perumahan modern. Gereja Katolik Regina Caeli terletak di kawasan perumahan Pantai Indah Kapuk di teluk Jakarta, tepatnya di Jl. Mediterania Boulevard, No.1, Pantai Indah Kapuk, Kapuk Muara, Kec. Penjaringan, Kota Jkt Utara, Daerah Khusus Ibukota Jakarta 14460. Gereja Katolik Regina Caeli memenuhi syarat sebagai desain arsitektur modern. Tampilan Gereja Katolik Regina Caeli memenuhi kriteria berciri arsitektur modern, yaitu geometri sederhana, miskin ornamen, dan penggunaan material modern (beton, baja \& kaca) untuk menghasilkan ruang bentang lebar.

Gereja Katolik Regina Caeli terletak di dekat pantai yang ditumbuhi tanaman bakau. Tema kawasan tepian pantai menjadi konteks bagi keberadaan Gereja Katolik Regina Caeli, sehingga berpeluang menyatukan secara harmonis konsep pantai dan konsep gereja. Pemandangan sekitar gereja yang didominasi oleh air laut, pantai, tanaman bakau dan kesejukan angin laun menjadi elemen-elemen yang diperttimbangkan dalam perancangannya. Arsitek Gereja Katolik Regina Caeli adalah Sardjono Sani. Konsep pantai, laut dan gereja sebagai bahtera (kapal) menjadi inspirasi yang ingin diungkapkan, juga diperkuat dengan konsep arsitektur modern dan menyatu dengan alam. 




Gambar 1. Letak Gereja Katolik Regina Caeli di dalam Kawasan Perumahan Pantai Indah Kapuk, Jakarta Utara.

Gereja Regina Caeli dari jauh terlihat seperti kapal yang sedang berlayar menuju suatu pelabuhan dengan nahkoda berupa salib Yesus. Semakin dekat mata memandang keunikan dan kekhasannya semakin terasa sebagai arsitektur gereja katolik. Walaupun material yang digunakan sederhana, Gereja Regina Caeli ramah lingkungan dan menyatu dengan kesejukan hutan bakau yang terbentang di pinggir pantai. Gereja Regina Caeli memang terleteak di dekat pantai dan hutan bakau. Jika dilihat dari dekat, Gereja Regina Caeli tampak seperti rumah panggung raksasa.

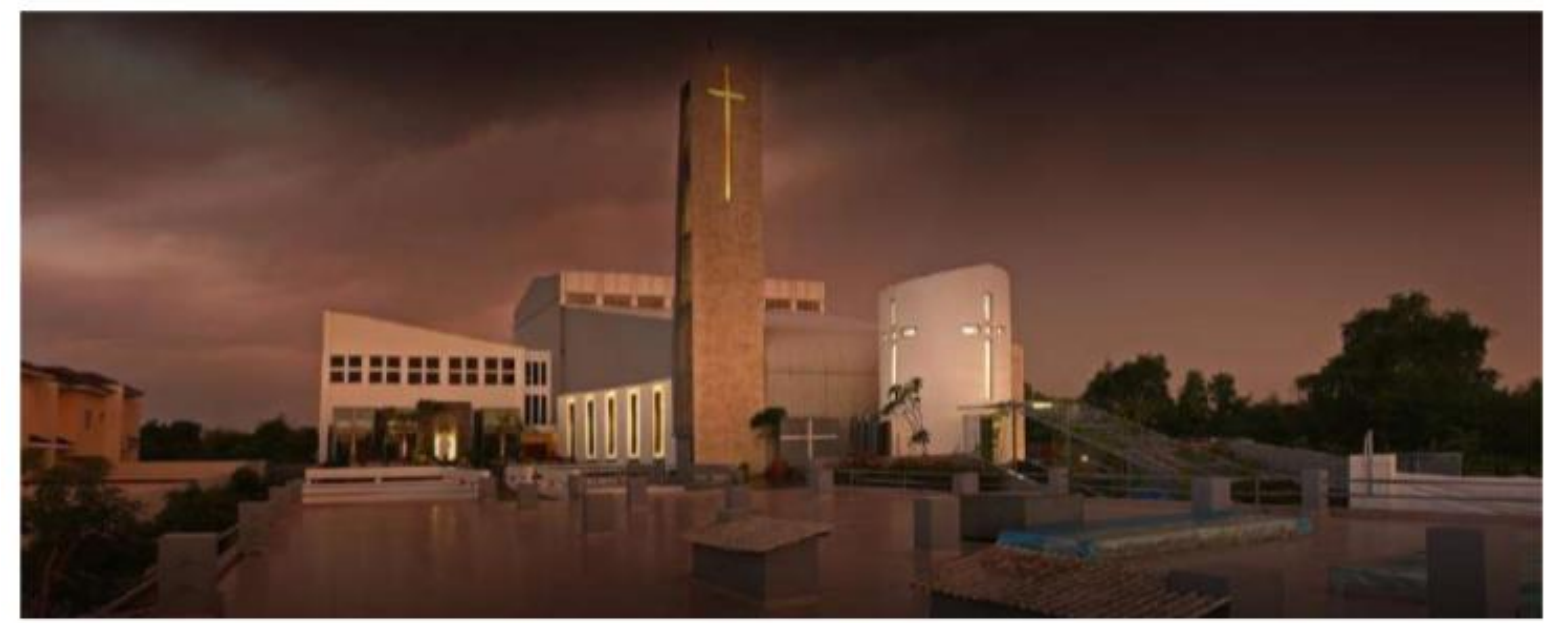

Gambar 2. Tampilan Gereja Katolik Regina Caeli dengan beberapa salib-salib bercahaya pada malam hari di pada tubuh bangunan yang tidak lazim (Sumber: http://biasteknoart.com)

Pada Gereja Katolik Regina Caeli, dinding di belakang altar tidak ditutup dengan tembok masif, tetapi menggunakan kaca (material transparan), sehingga rimbun dan kehijauan hutan bakau di dekatnya menjadi bagian menyatu dengan gereja pada eksterior dan interior. Menurut Sardjono Sani, konsep menyatu dengan alam dimaksudkan untuk memberi dimensi 
baru terhadap persepsi wujud suatu gereja katolik, yang selama ini steril dari lingkungan sekitar menjadi bangunan monumental yang terisolasi dari alam.

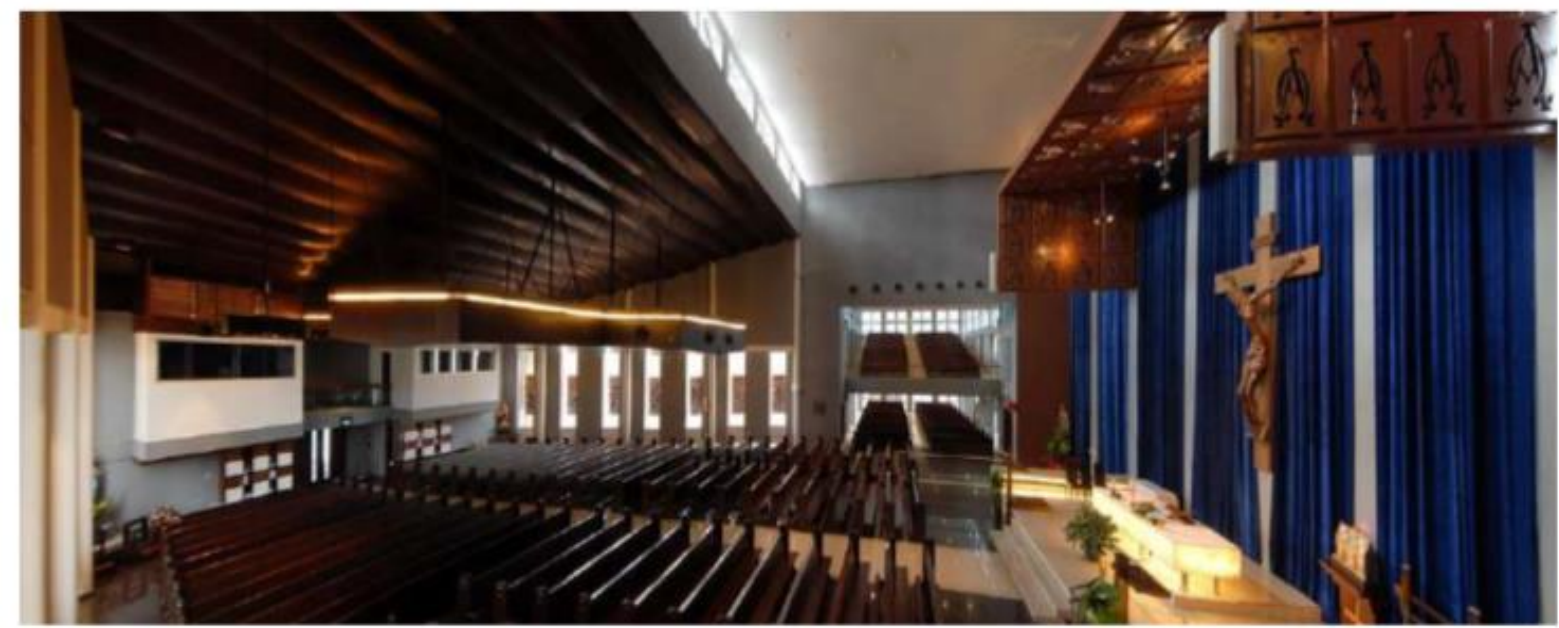

Gambar 3. Interior gereja Regina Caeli tertib sesuai prinsip arsitektur modern (Sumber: http://biasteknoart.com)



Gambar 4. Interior gereja Regina Caeli memiliki aksis di tengah

(Sumber: http://biasteknoart.com)

Perubahan jaman juga ingin ditampilkan dalam rancangan Gereja Katolik Regina Caeli. Semua perubahan mengenai persepsi baru, gereja yang ramah lingkungan dan berarsitektur modern, diwujudkan pada desain Gereja Katolik Regina Caeli agar lebih mengapresiasikan kekinian. Tembok di belakang gereja dibiarkan transparan supaya menyatu dengan asrinya hutan bakau yang ada di belakangnya. Salib Yesus yang berukuran besar dipasang pula pada bagian luar (menara). Dengan demikian, Gereja Katolik Regina Caeli tampak seperti kapal dengan nahkodanya adalah Salib Yesus. Estetika interior dan eksterior terpadu menjadi satu, membentuk arsitektur yang terbuka, konsisten dengan konsep bangunan gereja kekinian yang menyatukan bagian dalam (interior) dengan bagian luar (eksterior). 

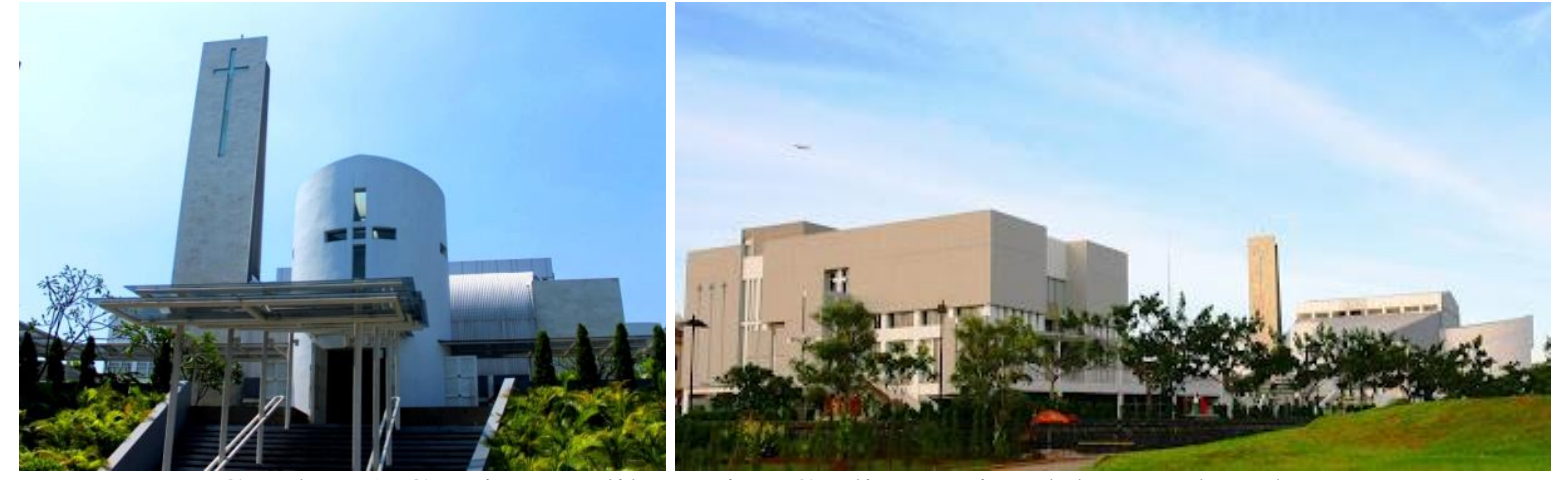

Gambar 5. Gereja Katolik Regina Caeli Pantai Indah Kapuk, Jakarta

(Sumber: http://biasteknoart.com)

Façade Gereja Katolik Regina Caeli bersih dari ornamen yang menempel (dibandingkan dengan gereja berlanggam gotik) berkesan berbeda dengan gereja era kolonial. Artinya, konsep modern minimalis benar-benar diterapkan sesuai ide sang arsitek. Fenomena inilah yang perlu dipertanyakan eksistensi ornamen sebagai simbol dalam arsitektur gereja. Secara tegas dapat dikatakan tampilan Gereja Katolik Regina Caeli memiliki ekspresi dan karakter bangunan anti ornamen, sehingga menyimpang dari falsafah gereja pada umumnya, namun memenuhi kriteris sebagai arsitektur modern. Pengaruh arsitektur modern juga berkembang di kota-kota besar di Indonesia, antara lain Jakarta. Gereja Katolik Regina Caeli di Pantai Indah Kapuk Jakarta dirancang dengan gaya arsitektur "modern minimalis". Sardjono Sani, menjelaskan, ada niat untuk mengenalkan dimensi baru terhadap persepsi wujud gereja yang berbeda. Desain gereja selama ini menurutnya sudah terpakai lama dan terus dijadikan acuan. Padahal, zaman terus berubah, maka perubahan persepsi diakomodasi dalam desain gereja yang baru agar lebih mengapresiasi kekinian; mengikuti jaman. Pada sisi yang lain, ide "mengikuti jaman", berlawanan dengan pernyataan Paus Benediktus XVI, Pemimpin tertinggi gereja Katolik sedunia. Pada tahun 2011, Paus Benediktus XVI membentuk komisi baru dalam hirarki kepemimpinan gereja Katolik di bawah Congregation for Divine Worship. Pembentukan komisi baru (dengan status: "very urgent") ini didasarkan pada keprihatinan Paus atas "penyimpangan" yang begitu banyak terjadi pada desain arsitektur gereja Katolik di seluruh dunia. Desain gereja katolik ditengarai mulai meninggalkan elemen-elemen kunci demi mengikuti jaman, begitu keprihatinan Paus.

Upaya mengkaji keberadaan simbol dan ornamen-simbolis dalam arsitektur Gereja Katolik Regina Caeli dilakukan dengan membaca data sekunder berupa informasi tentang konsep arsitektur gereja dari arsitek pembuatnya. Data gambar (foto) digunakan sebagai pelengkap diperoleh dari situs yang memuat informasi Gereja Katolik Regina Caeli dan arsitek yang merancangnya. Data rancangan gereja kemudian dibaca dan dibandingkan dengan prinsipprinsip rancangan gereja menurut pedoman baku, terutama dokumen konsili Vatikan II. Dari proses pembandingan data lapangan (konsep dan desain) dengan pedoman resmi dan diperiksa dengan prinsip arsitektur modern, diperoleh temuan-temuan tentang karakteristik rancangan gereja pada kasus yang dianalisis. Temuan kemudian dibahas dan diangkat ke ranah teoretis dan dirumuskan temuan ilmiah berupa prinsip atau konsep rancangan yang mendasari rancangan fisik Gereja Katolik Regina Caeli. 


\section{HASIL PENELITIAN DAN PEMBAHASAN}

Keberadaan Simbol Salib pada Gereja Katolik Regina Caeli Salib adalah simbol yang menonjol pada rancangan Gereja Katolik Regina Caeli. Salib ada pada menara dan beberapa dinding. Jumlah salib yang ada dibeberapa tempat ini tidak lazim terjadi pada gereja katolik yang ada sebelumnya. Umumnya simbol salib hanya ada satu atau dua saja, satu paling menonjol karena diletakkan pada tempat yang tinggi. Salib pada gereja berarsitektur Eropa atau Kolonial keberadaannya terkait dengan upaya menciptakan simetrika atau asimetrika pada gubahan massa bangunan. Simbol salib pada gereja lama (berarsitektur Eropa atau kolonial) dibuat dalam ukuran kecil dan dimaksudkan menjadi mahkota pada titik puncak atap atau menara gereja. Salib diletakkan pada puncak atap atau menara yang dibangun untuk menciptakan tampilan megah. Jika menggunakan beberapa salib, ukuran salib tetap kecil dan menjadi elemen final pada puncak atap atau menara yang tinggi. Selain Salib, kadang pada puncak menara gereja katolik sering dipasang simbol ayam, terkait dengan peristiwa "ayam berkokok tiga kali" pada pagi hari ketika Santo Petrus menyangkal Yesus. Ayam juga dikaitkan dengan simbolisasi hewan yang menyambut datangnya pagi, harapan, terbitnya matahari, maka menandai altar yang menghadap ke timur (imam menghadap ke timur).


Gambar 6. Salib eksterior Gereja Katedral Jakarta (kiri) dan Gereja Katedral Bogor (kanan)

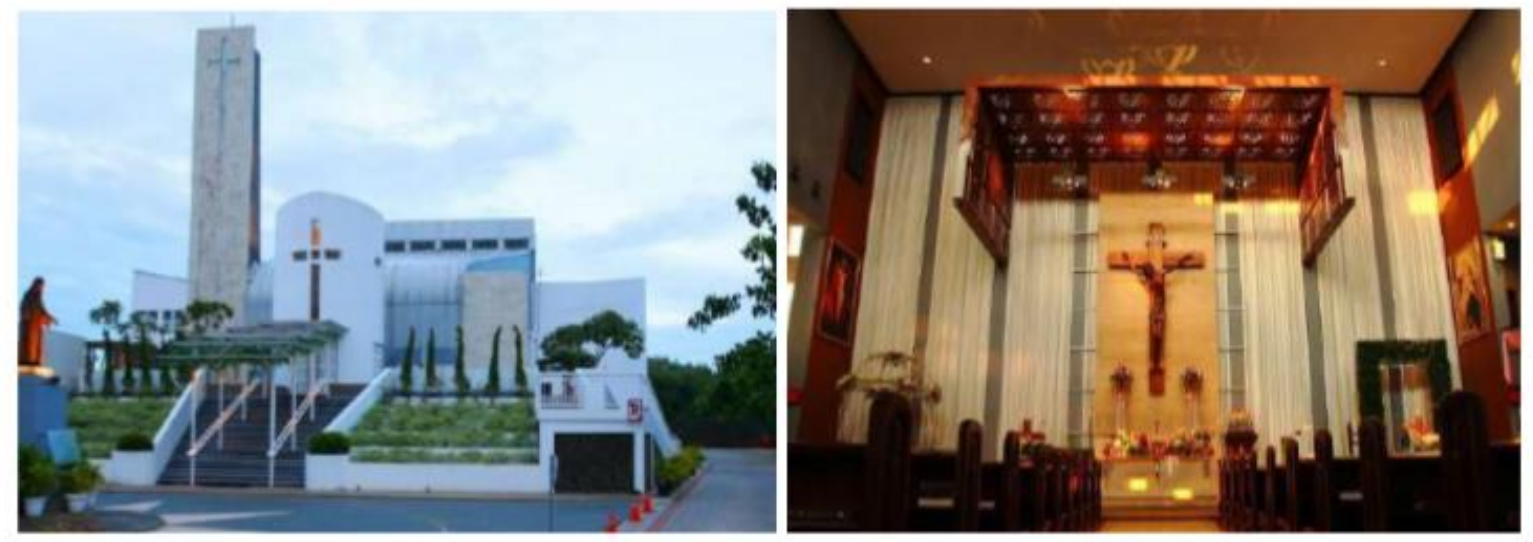

Gambar 7. Salib eksterior dan Salib interior pada Gereja Katolik Reginan Caeli

Pada rancangan gereja katolik ada dua kecenderungan tentang keberadaan salib, yaitu salib pada eksterior bangunan dan salib di dalam bangunan. Salib eksterior digunakan untuk mengungkapkan keberadaan gereja kepada dunia luar, sedangkan salib interior difungsikan 
untuk memfokuskan dan meningkatkan kualitas ibadah. Dalam gereja katolik, fokus Misa Kudus adalah altar dan salib yang ada di atasnya menjadi simbolisasi kehadiran Yesus yang hadir dan bertahta di singgasana yaitu Salib. Oleh karenanya, corpus Yesus selalu ada dalam salib interior pada setiap gereja katolik (bahkan salib orang katolik selalu ada corpus Yesus, salib gereja lain yang bukan katolik tanpa corpus Yesus).

Rancangan simbol salib pada Gereja Katolik Regina Caeli yang memanfaatkan lobang dinding dibentuk menjadii salib pada dinding mengingatkan teknik yang sama pada rancangan Church of Light yang diciptakan Tadao Ando. Salib mengalami kreasi menjadi materi bersifat "void" bukan lagi "mass" yang telah menjadi kebiasaan. Perubahan dari massa ke rongga pada wujud salib inii secara substansial sama tetapi secara presentasi memang berbeda. Orang sudah terbiasa menyembah salib berwujud massa benda akan tergerak ke sujud pada salib berupa rongga (cahaya). Salib pada Gereja Katolik Regina Caeli dan Church of the Light diperlihatkan di bagian luar sebagai bagian dari tekstur dinding membentuk bentuk salib geometri yang estetis. Ukuran salib juga dibuat besar, lebih besar dari salib-salib gereja berarsitektur Eropa atau Kolonial, sehingga terkesan menonjol pada eksterior bangunan. Salib berwujud rongga semacam itu lantas menjadi elemen eksterior yang fugsional, simbolis sekaligus estetis. Artinya teknik penggunaan konsep salib rongga merupakan kemajuan ke arah imaterialisasi arsitektur, bergerak dari massa ke rongga, yang memungkinkan kreatifitas dengan cara imetarialisasi.
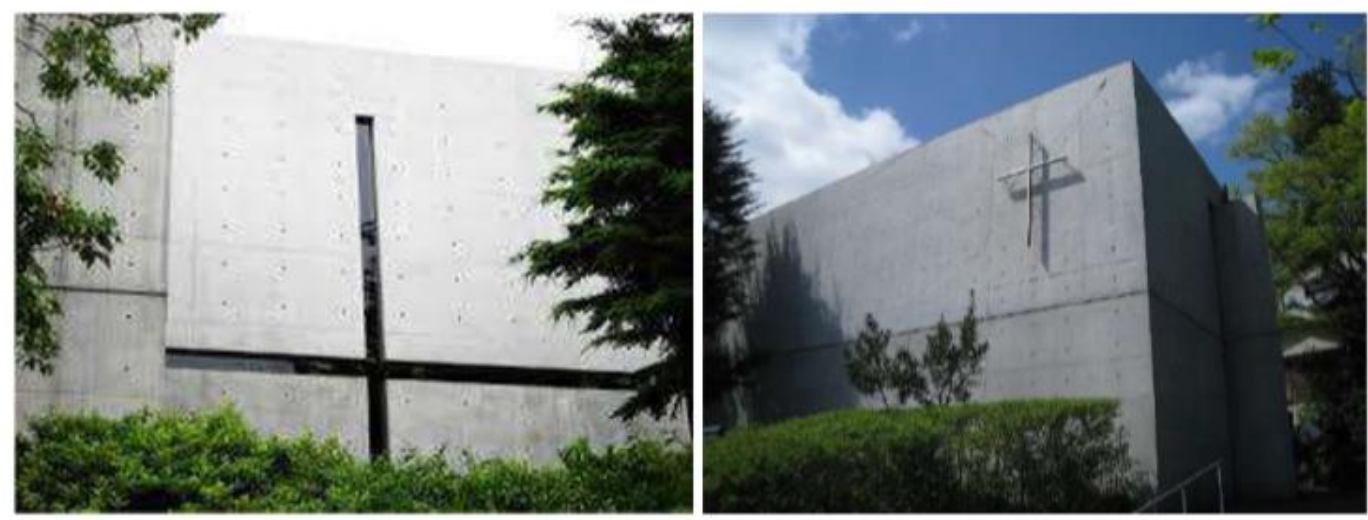

Gambar 8. Teknik pemasangan simbol Salib pada Church of the Light.
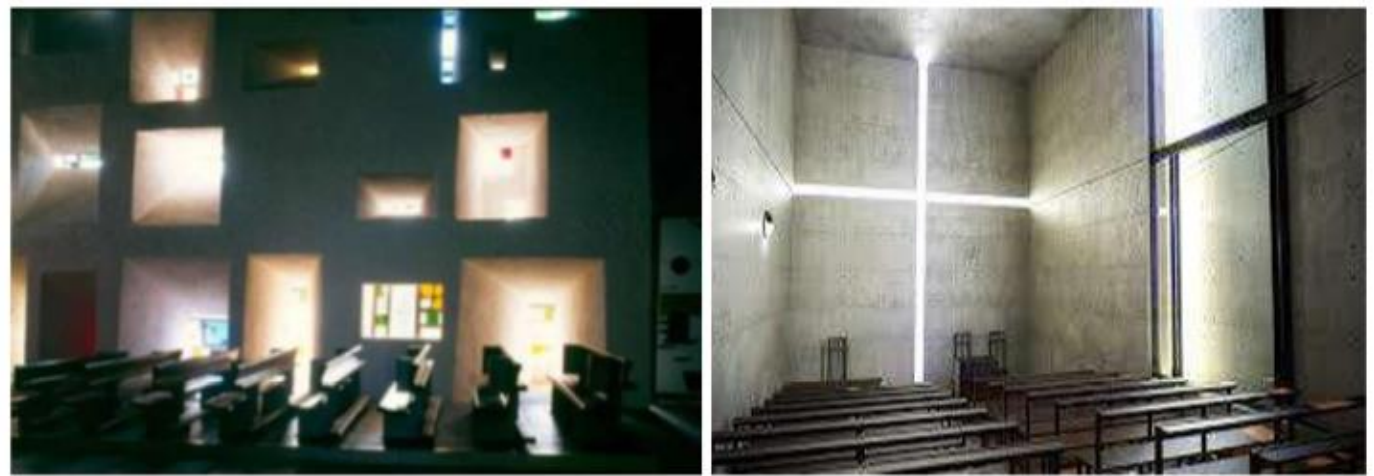

Gambar 9. Interior Ronchamp Chapel dan Curch of the Light memanfaatkan cahaya matahari membentuk Salib. 
Teknik salib sebagai rongga pada Gareja Katolik Regina Caeli dan Church of the Light mengingatkan pada Ronchamp Chapel, yang memanfaatkan cahaya untuk membentuk suasana interior yang sakral berbasis konsep "Tuhan hadir dalam cahaya". Salib berupa massa material pada Ronchamp Chapel karya Le Corbusier sangat kecil dan hanya satu di puncak menara. Salib pada Church of the Light karya Tadao Ando lebih besar dan terletak di satu tempat yaitu ruang dalam bangunan utama. Salib pada Gereja Katolik Regina Caeli karya Sarjono Sani ada beberapa buah, ukurannya besar-besar, menggunakan teknik yang sama dengan Ando, yaitu memanfaatkan lobang dinding dan cahaya untuk membentuk simbol salib pada ruang dalam (interior). Artinya, Gereja Katolik Regina Caeli menggunakan unsur-unsur arsitektur pada rancangan gereja sebelumnya, yaitu Ronchamp Chapel dan Curch of the Light. Tentu dapat dijelaskan, sebab keduanya adalah preseden, desain yang mendahuluinya dan terjadi interferensi dalam desain. Secara alamiah, kebudayaan manusia sarat dengan tanda dan simbol. Contohnya, "bendera"; "lambang negara" atau "lambang keagamaan: bulan-sabit, swastika, salib" dan sebagainya adalah simbol-simbol penting. Simbol merupakan bagian dari ekspresi, yakni pencerminan keadaan dari suatu komponen semiotik yang aktif dan satu cara penyampaian agar pengamat dapat mengartikan makna tanda-tanda tertentu. Ekspresi arsitektur adalah pernyataan mental dari suatu bentuk arsitektur yang umumnya menggunakan referensi dasar dari pengalaman seorang pengamat dari bentuk-bentuk arsitektur yang pernah dialaminya. Apabila suatu isyarat, simbol maupun ekspresi adalah suatu hal nyata, maka seseorang yang mengamati mengartikan hal yang diamati sama dengan penciptanya mengartikan. Bangunan relijius selalu membutuhkan simbol sebagai ekspresi iman. Simbol menjadi penanda identitas dan juga "penggambaran yang sangat kaya dan mendalam" suatu keyakinan dan iman.

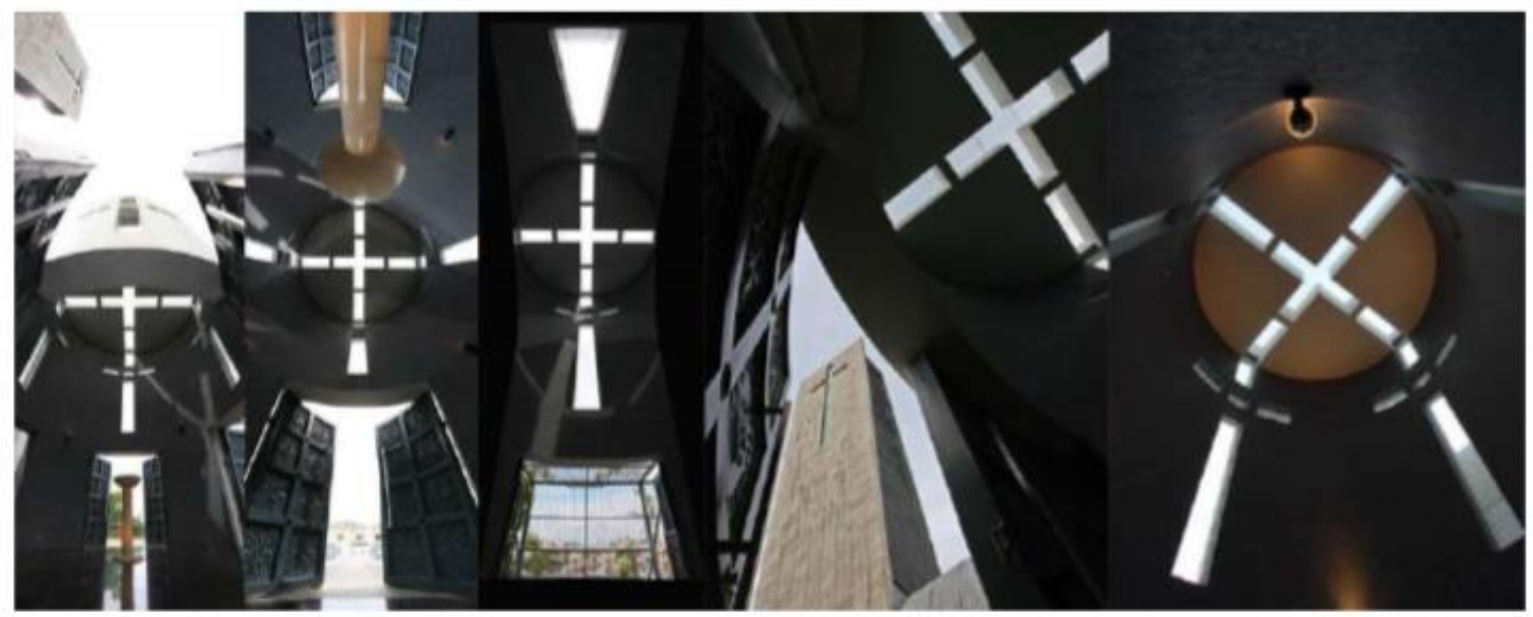

Gambar 10. Interior Gereja Katolik Regina Caeli dengan salib-salib yang dibentuk dari lobang cahaya.

\subsection{Keberadaan Ornamen Sebagai Penguat Sacred Symbol}

Gereja Katolik Regina Caeli pada bagian ruang-dalam (interior) terdapat ornamen baku berupa panel-panel terkait dengan doa "jalan salib", sebanyak 14 panel. Panel-panel dipasang di sepanjang dinding sisi kiri dan kanan ruang utama gereja. Panel-panel berwarna coklat dengan isi ornamen peristiwa perjalanan dan penyaliban Yesus di Golgotha. Panel-panel seperti ini lazim ada dan menjadi bagian penting dalam arsitektur gereja. Pada altar juga terdapat panel-panel tulisan "Alfa \& Omega", simbol Kristus adalah awal dan akhir, maka memperkuat simbolisasi pada ruang altar. Semua tempat ibadah memiliki simbol dan ornamen digunakan untuk memberikan gambaran tentang sesuatu yang lebih besar atau lebih 
penting. Simbol dan ornamen adalah instrumen fisik penting untuk menghadirkan sacred space. Ornamen bagi manusia menjadi sarana "menghadirkan" Tuhan yang tidak bisa dilukiskan dengan kata-kata. Beberapa tempat ibadah seringkali memiliki banyak simbol dan ornamen seperti Gereja bergaya Barok-Rokoko, Pura Bali atau Kelenteng.

Ornamen penting bagi tempat ibadah agama apapun. Ornamen menjadi unsur penting pada klenteng Tri Dharma di Bali meskipun berakulturasi dengan budaya setempat [34]. Ornamen juga menjadi elemen penting bagi masjid-masjid di kawasan Pantura, Jawa Tengah, karena menampilkan keindahan yang mengandung pesan [35], juga pada Masjid Besar Kauman Semarang [36]. Ornamen yang diciptakan beragam dari simbol Karang Bhoma bahkan menjadi elemen penting pada Kori Agung Pura di Kecamatan Blahbatuh Gianyar [37]. Ornamen dan simbol di kalangan masyarakat Dayak Kenyah selalu dikaitkan dengan sesuatu yang sakral [38].

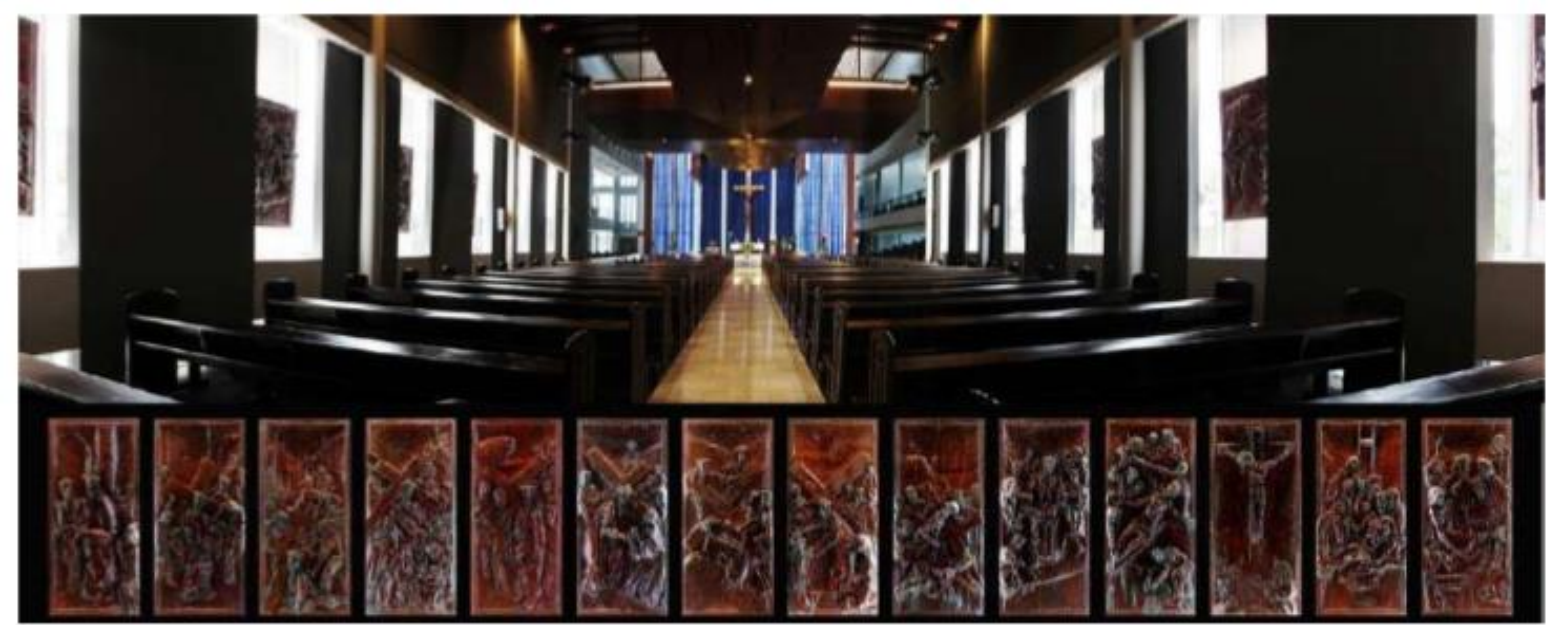

Gambar 11. Panel Jalan Salib pada gereja Regina Caeli (Sumber: http://biasteknoart.com)

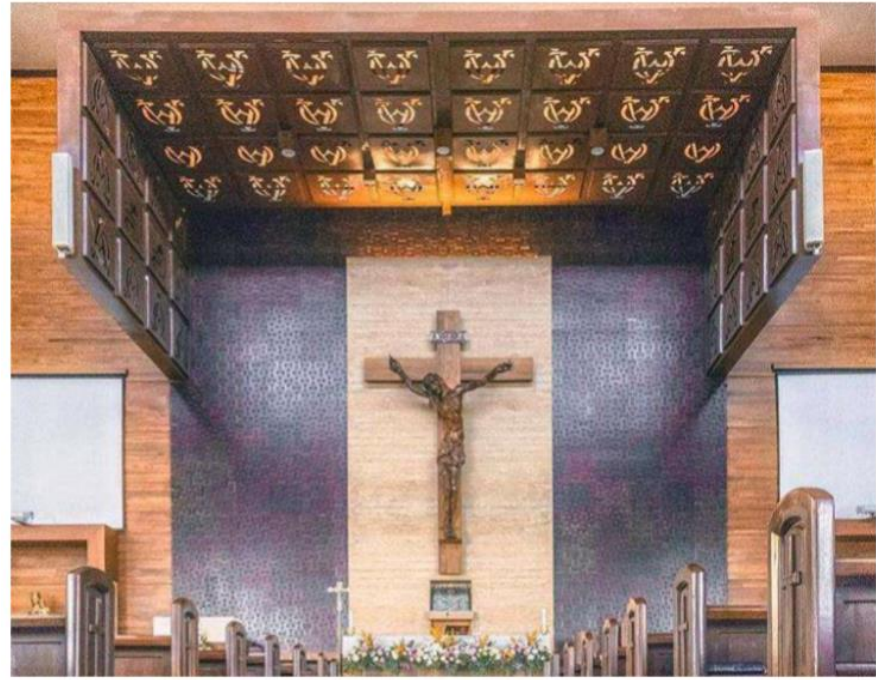

Gambar 12. Altar pada Gereja Katolik Regina Caeli terdapat simbolisasi Alfa dan Omega.

Dalam praktek, arsitek harus mencari dan menampilkan bentuk-bentuk simbolik untuk menyatakan: ... the church must be a symbolic structure, it must be informed from the outset by a theological understanding of its purpose [39]. Otto von Simson juga menyatakan :.. all 
things are symbolic of the reality behind the symbol. This is why for the medieval man the symbol is the only objectively valid definition of reality (Srisadono, 2012). Simbol-simbol tersebut diwujudkan dalam bentuk sacred images. Sacred images dalam Gereja Katolik ditampilkan dalam bentuk frescoes, mosaic, ukiran kayu dan batu, lukian icon dan kaca patri (stained glass). Fungsi dari sacred images tersebut adalah: (1) untuk memperingati orang kudus atau peristiwa tertentu; (2) membantu umat untuk fokus dalam doa dan meditasi; (3) sebagai media pembelajaran iman bagi anak-anak; (4) pewartaan isi Kitab Suci dalam media gambar. Makna simbol dalam bangunan religi adalah suatu keharusan. Memang ada tarik menarik antara fungsi dan simbol dalam arsitektur bangunan relijius. Dalam kasus Gereja Katolik Regina Caeli terjadi kompromi arsitektur yang menentukan tampilan eksterior dan interior sesuai dengan konteks yang terkait.
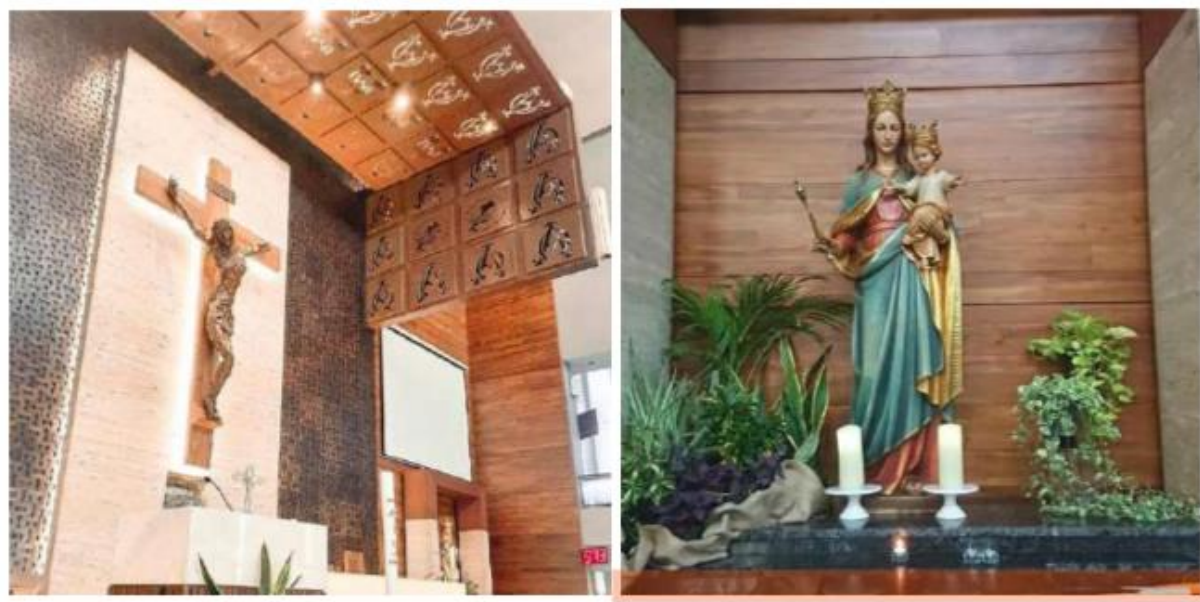

Gambar 12. Salib Yesus (kiri) dan Patung Bunda Maria Ratu Surga di Gereja Katolik Regina Caeli

Jika desain arsitektur tempat ibadah steril dari ornamen, maka ada 2 bagian penting yang hilang, yaitu identitasnya sebagai bangunan ibadah dan jatidirinya (jiwa) sebagai bangunan sakral khas agama tertentu. Pada bangunan Klenteng, misalnya, jika semua ornamen (ukiran) dan simbol berupa patung dewa-dewi dihilangkan; atau desain arsitektur Masjid tanpa simbol Bulan-Bintang dan tulisan kaligrafi di dalam ruang, maka identitas dan jatidirinya diragukan sebagai bangunan ibadah dan bangunan relijius. Artinya, bangunan religius kehilangan "jiwa"-nya sebab "jiwa" dari bangunan religius ada pada simbol dan ornamen-simbolis. Titik inilah yang menjadi inti kritik dari Paus Benediktus XVI tertuju pada arsitektur gereja yang modern namun sepi dari simbol dan ornamen katolik.

\subsection{Modern-Minimalis plus Ornamen?}

Fakta bahwa Gereja Regina Caeli dirancang dengan paradigma arsitektur modern sudah jelas dinyatakan oleh arsitek yang merancang. Perumahan PIK adalah perumahan baru yang modern, maka sebagai konteks visual tentu menentukan dan memberi arah bagi arsitek perancangnya. Dengan demikian, arsitek berusaha menemukan titik temu rancangan gereja dengan konteks visual di sekelilingnya sebagai salah satu penentu karakter rancangan. Fakta bahwa dalam rancangan Gereja Regina Caeli digunakan simbol salib dan ornamen panel "jalan salib" tampak dengan nyata. Bagaimanapun juga gereja adalah tempat suci dan orang katolik selalu dekat dengan simbolisme dan benda-benda simbolis. Penghayatan iman dalam katolik selalu terkait dengan simbol-simbol yang menjadi elemen pendukung. Elemen- 
elemen simbolis begitu penting, sebab simbol mengacu pada yang disimbolkan. Keberadaan keduanya (interior dan eksterior) terjadi secara harmonis, namun jika dilihat dari sudut pandang arsitektur modern terjadi "perselingkuhan arsitektur". Bagi arsitektur modern, keberadaan ornamen dalam desain adalah sebentuk kejahatan; arsitektur modern menolak ornamen. Dalam pernyataan sederhana dirumuskan singkat: tampilan eksterior cenderung berciri arsitektur modern minimalis, sedangkan tampilan interior berciri arsitektur gereja katolik yang menggunakan simbolisme berbasis ajaran gereja. Tampilan eksterior cenderung didominasi unsur-unsur geometri yang lugas, tanpa ornamen, dan dinding yang bersih mendukung tampilan geometri menjadi kuat. Tampilan interior dihiasi dengan elemenelemen simbolisme, mulai dari altar hingga seluruh dinding ruang dalam. Artinya, rancangan gereja Regina Caeli tidak sepenuhnya arsitektur modern, hanya bagian eksterior dan geometri denah, sedangkan elemen-elemen pengisi ruang menggunakan simbolisme gereja. Dua fakta yaitu eksterior dan interior berciri beda, mengingatkan pada konflik lama antara mazhab "form follows function" dan mashab "gaya arsitektur pra-modern". Konflik dimulai ketika Arsitek Austria, Adolf Loof menyatakan: "ornamen arsitektur itu adalah kejahatan" : "Ornament and Crime" was first spoken in a lecture on 21 January 1910 in Vienna and first published in Cahiers d'aujord' hui 5/1913 by the influential and self-consciously "modern" Austrian architect Adolf the essay was translated into French and did not appear in German until 1929 (Janet Stewart, Fashioning Vienna: Adolf Loos's Cultural Criticism). Ketika paham arsitektur modern "no ornamen" diterapkan pada arsitektur bangunan kantor, bangunan supermarket, atau bangunan umum lainnya, tidak muncul persoalan. Masalah muncul ketika diterapkan pada arsitektur Gereja Katolik yang mementingkan pemakaian simbol-simbol, karena simbol-simbol mendukung ungkapan iman yang membutuhkan media visual, yaitu simbol dan ornamen dalam ruang.

Mazhab "form follows function", tidak sama sekali menolak kehadiran ornamen, namun sejauh ornamen itu memiliki "fungsi", maka ornamen masih ditoleransi keberadaannya. Pertanyaannya: apakah "simbol" juga masuk kategori "fungsi" bagi mereka? Gaya "Gothic" apalagi gaya "Barok-Rokoko" yang sarat dengan "complicated symbols" jelas ditolak oleh pengikut mazhab "form follows function". Dalam kasus Gereja Katolik Regina Caeli terjadi kompromi arsitektur : aspek luar (eksterior) menyesuaikan konteks jaman dana konteks setempat, sedangkan aspek dalam (interior) menaati prinsip-prinsip tata ruang geereja katolik sebagai gereja tempat berdoa yang relijius. Simbol salib pada Gereja Regina Caeli, salib eksterior dan salib interior, adalah mendukung kebutuhan fungsi spiritual, selain makna identitas dan jatidiri. Keberadaan ornamen „panel jalan salib“ dan panel „alfa dan omega“ merupakan fasilitas yang harus ada untuk mendukung doa dalam perayaan paskah. Dengan demikian, keberadaan simbol dan ornamen-imbolis merupakan kebutuhan dasar yang harus dipenuhi dalam rancangan sebuah gereja katolik. Simbol dan ornamen-simbolis menjadi syarat dasar dalam rancangan gereja katolik yang memenuhi syarat sesuai gerejani.

\section{KESIMPULAN}

Gereja Katolik Regina Caeli merupakan gereja dengan basis rancangan arsitektur modern, pada tampilan eksterior gereja dilengkapi dengan simbol agama Katolik yang khas berupa salib. Simbolisme Salib dan ornamen-simbolis ditemukan dalam rancangan interior dan eksterior gereja, maka secara hakiki rancangan gereja tidak konsisten dengan prinsip arsitektur modern, khususnya bertentangan dengan slogan "ornamen adalah kejahatan" (dirumuskan oleh Adlof Loos). Keberadaan simbol salib bercahaya dan ornamen-simbolis panel jalan salib hakekatnya menambah pengalaman spiritual, terkait dengan keunikan 'sense 
of place', 'spiritual of place' dan 'meaningfull experience' seperti pada gereja katolik pada umumnya. Artinya, meskipun rancangan arsitektur didasari paradigma arsitektur modern (minimalis), namun keberadaan simbol dan ornamen-simbolis tetap menjadi kebutuhan dan keharusan. Dengan demikian, arsitektur gereja katolik Regina Caeli merupakan perpaduan arsitektur modern (minimalis) yang dilengkapi dengan simbolisme berbasis nilai, iman, dan ajaran katolik; bukan karya arsitektur gereja yang berbasis arsitektur modern murni. Rancang eksterior berkarakter arsitektur modern, rancangan interior berkarakter arsitektur gereja katolik yang menggunakan simbolisme gereja katolik.

\section{REFERENSI}

R. Trisno, Antariksa, and P. Salura, "Ekspresi Eksistensial Sakral Katolik pada Arsitektur Gereja Theresia di Jalan Gereja Theresia No . 2 , Menteng Jakarta Pusat," in Seminar Rumah Tradisional 2014 - Transformasi Nilai-nilai Tradisional dalam Arsitektur Masa Kini, 2014.

R. Trisno, A. Antariksa, and P. Salura, "Pengaruh Fungsi Ritual pada Bentuk Arsitektur, Kasus Studi : Gereja Katedral, Gereja Theresia,Gereja Salib Suci, Gereja Santo Matias Rasul dan Gereja Stella Maris," NALARs, vol. 15, no. 1, p. 25, 2016.

Srianovita, L. Betteng, and J. Rengkung, "Gereja Toraja di Manado: Simbolisme dalam Arsitektur," Manado, 2015.

M. Al Mujabuddawat, "Simbolisme Kompleks Bangunan Situs Ki Buyut Trusmi Cirebon," Kapata Arkeol., vol. 12, no. 2, pp. 175-190, 2016.

R. H. I. Sitinjak and S. de Jong, "Studi Implementasi Konsep Ruang Heterotopia Pada Interior Gereja Katolik Tritunggal Mahakudus Tuka-Dalung Bali,” Dimens. Inter., vol. 5, no. 1, p. pp.12-22, 2007.

L. K. Wardani, "Simbolisme Liturgi Ekaristi Dalam Gereja Katolik," Dimens. Inter., vol. 4, no. 1, pp. 17-24, 2006.

M. Chrisylla, "Simbolisasi pada Rancangan Arsitektur Gereja Katolik Santo Petrus dan Gereja Katolik Santa Perawan Maria Tujuh Kedukaan di Kota Bandung," ARTEKS J. Tek. Arsit., vol. I, no. 1, pp. 1-14, 2016.

E. Veronica, "Pengaruh Liturgi Gereja Katolik Roma pada Interior Gereja Kelahiran Santa Perawan Maria," Dimens. Inter., vol. 6, no. 2, pp. 123-133, 2008.

F. I. Tantu and S. M. Sari, "Re-Design Interior Gereja Katolik Santo Paulus Di Surabaya Berdasarkan Ajaran Allah Tritunggal," J. Intra, vol. 2, no. 2, pp. 337-341, 2014.

E. T. Herliana, "Unsur - Unsur Bangunan Pembentuk Karakter Arsitektural Pada Kompleks Gereja Katedral Bogor,” J. Arsit. KOMPOSISI, vol. 10, no. 6, p. 397, 2019.

D. S. M. Santoso, "Pengaruh Gaya Desain Gotik dan Kolonial Belanda Terhadap Efek Pencahayaan Alami pada Gereja Katolik Hati Kudus Yesus di Surabaya," Dimens. Inter., vol. 12, no. 1, 2014.

H. Renaldi, "Fungsi-Makna-Bentuk Gereja Katedral Santo Petrus Bandung," in Seminar Ikatan Peneliti Lingkungan Binaan Indonesia (IPLBI) 2017, 2017, pp. A303- A310.

A. Yunani, "Gereja Hati Yesus Yang Maha Kudus - Katedral (Sejarah Gereja Katolik di Sulawesi Selatan dan Tenggara),” J. Lekt. Keagamaan, vol. 15, no. 1, p. 125, 2018.

L. K. Wardani and A. Isada, "Gaya Desain Kolonial Belanda Pada Interior Gereja Katolik Hati Kudus Yesus Surabaya,” Dimens. Inter., vol. 7, no. 1, pp. 52-64, 2009.

S. M. Sari and S. A. Fransisca, "Kajian Perwujudan Nirmana Interior Gereja Katolik Santo Paulus di Surabaya dengan Pendekatan Semiotik,” Dimens. Inter., vol. 6, no. 1, pp. 24 34, 2008. 
A. Yunani, "Gereja Santo Antonius Purbayan: Sejarah Awal Gereja Katolik Belanda di Solo," J. Lekt. Keagamaan, vol. 14, no. 1, p. 229, 2018.

Y. D. Srisadono, "Konsep Sacred Space Dalam Arsitektur Gereja Katolik," Melintas, vol. 28, no. 2, pp. 182-206, 2012.

S. M. Sari, "Wujud Budaya Jawa Sebagai Unsur Inkulturasi Interior Gereja Katolik," Dimens. Inter., vol. 5, no. 1, p. pp.44-53, 2007.

S. M. Sari and J. Setyaprana, "Inkulturasi budaya Jawa dalam interior Gereja Katolik Redemptor Mundi di Surabaya,” Dimens. Inter., vol. 5, no. 2, pp. 80-89, 2007.

I. W. Wardani, A. A. G. D. Sudarsana, and S. M. Swardana, "Aplikasi Filosofi Tri Hita Karana dalam Konsep Perencanaan Lansekap Gereja Katolik Santa Maria Immaculata, Tabanan," J. Arsit. Lansek., vol. 1, no. 1, pp. 20-29, 2015.

M. Basri, "Elemen-elemen Arsitektur Vernakular dalam Analisa Ruang dan Bentuk pada Gereja Pohsarang," J. RUAS, vol. 15, no. 1, pp. 35-47, 2017.

I. A. Agustina, A. Wibisono, and I. Santosa, "Analisa Sinkretisme Agama dan Budaya Melalui Transformasi Elemen Visual Bernilai Sakral pada Gereja Katolik Ganjuran,” J. Desain Inter., vol. 2, no. 2, p. 73, 2018.

Y. Don Bosko Bakok, "Musik Liturgi Inkulturatif di Gereja Ganjuran Yogyakarta,” Resital J. Seni Pertunjuk., vol. 14, no. 1, 2018.

A. Kristianus, "Dialektika Budaya Dayak: Inkulturasi Agama Katolik dengan Budaya Dayak Kayaan," Animage J. Stud. Kult., vol. II, no. 22, pp. 87-93, 2017.

A. Lestary, "Analisis Semiotik Makna dan Fungsi Ornamen pada Gereja Santa Maria De Fatima Jakarta Barat yang Dipengaruhi Budaya Cina," Skripsi, tidak dipublikasikan, Universitas Sumatera Utara, 2018.

Y. D. Purbadi, "Tata Suku dan Tata Spasial pada Arsitektur Permukiman Suku Dawan di Desa Kaenbaun di Pulau Timor," Universitas Gadjah Mada, 2010.

F. H. Istanto, "Arsitektur 'Guna dan Citra' Sang Romo Mangun in Memoriam: Yusuf Bilyarta Mangunwijaya 6 mei 1029 - 10 Februari 1999,” Dimens. Tek. Arsit., vol. 27, no. 2, pp. 40-47, 1999.

N. R. Burhany, "Dialog Kritis Trilogi Vitrivius Vs. Dwilogi Mangunwijaya," Mektek, vol. X, no. 1, pp. 54-61, 2010.

I. N. Warnata, "Guna dan Citra dalam Arsitektur," Undagi, vol. 5, no. 1, pp. 1-8, 2017.

H. Yamanto, "Tektonika dalam Semiotik Asitektur, Studi Karya YB Mangunwijaya," Tesis, tidak dipublikasikan, Universitas Diponegoro, 2003.

M. I. Hidayatun, J. Prijotomo, and M. Rachmawati, "Materials as Part of The Identity of Indonesian Architecture: Locality and Universality Value in Mangunwijaya and Eko Prawoto Works," in SB Dubai Paper, 2016, pp. 1-8.

R. G. Sunaryo, "Mengikuti Langkah Pikir Romo Mangun: Sebuah Tinjauan Mengenai Metode Perancangan Arsitektur Yusuf Bilyarta Mangunwijaya," Dimens. (Jurnal Tek. Arsitektur), vol. 35, no. 1, pp. 41-45, 2007.

L. K. Wardani, "Fungsi, Makna dan Simbol: Sebuah Kajian Teoritik," in Seminar Jelajah Arsitektur Nusantara 101010, 2008, pp. 1-27.

S. M. Sari and R. S. Pramono, "Kajian Ikonografis Ornamen pada Interior Klenteng Sanggar Agung Surabaya," Dimens. Inter., vol. 6, no. 2, pp. 73-84, 2008.

B. Supriyadi, "Kajian Ornamen Pada Mesjid Bersejarah Kawasan Pantura Jawa Tengah,” J. Ilm. Peranc. Kota dan Permukim., vol. 7, no. 2, pp. 106-121, 2006.

A. Sidiq, "Masjid Besar Kauman Semarang: Sebuah Kajian Gaya Arsitektur dan Ornamen," J. Anal., vol. XVIII, no. 01, pp. 39-58, 2011. 
I. K. M. Wijaya and N. W. M. Mustika, "Tipologi Ornamen Karang Bhoma Pada Kori Agung Pura di Kecamatan Blahbatuh, Gianyar," UNDAGI J. ArsitekturWarmadewa, vol. 4, no. 2, pp. 48-55, 2016.

M. S. Mayasari, L. Tulistyantoro, and M. T. Rizqy, "Kajian Semiotik Ornamen Interior pada Lamin Dayak Kenyah,” J. Intra, vol. 2, no. 2, pp. 288-293, 2014.

P. Hammond, Liturgy and Architecture. New York: Columbia University Press, 1961. 